\title{
HUBUNGAN PELAKSANAAN CUCI TANGAN OLEH PERAWAT SEBELUM DAN SESUDAH BERINTERAKSI DENGAN PASIEN TENTANG PENCEGAHAN INFEKSI NOSOKOMIAL DI RS PTPN II BANGKATAN BINJAI TAHUN 2017
}

\author{
Relationship of the Implementation of Handwork by Nurse Before and After \\ Investigation of Patients About Prevention of Prevention of Nosocomial \\ Infection in Bangkatan PTPN II Hospital 2017
}

\author{
Yunita Sarah Nadeak ${ }^{1}$ \\ ${ }^{1}$ Dosen Akademi Keperawatan Sehat Binjai \\ E-mail: yunitasarahnadeakskepmkm@gmail.com
}

\begin{abstract}
Abstrak
Cuci tangan adalah suatu hal sederhana untuk meghilagkan kotoran atau kuman dan meminimaliris kuman yang ada di tangan, dengan menguyur air. dan dapat di lakukan dengan menambah bahan tertentu seperti sabun. Degan ini hubugan pelaksanaan cuci tangan oleh perawat sebelum dan sesudah berinteraksi degan pasien tentang pencegahan infeksi, Jenis penelitian ini adalah metode penelitian survey yang digunakan untuk mengumpulkan data atau informasi tentang Keberhasilan pelaksanaan cuci tangan. Populasi dalam penelitian ini adalah perawat. Sampel yang digunakan adalah ketidak patuhan perawat dalam mencuci tangan sebelum dan sesudah berinteraksi egan pasien. Teknik pengambilan sampel adalah total sampling. Analisa data dengan teknik uji chi-square dengan menggunakan program SPSS (Statiscal Product and Service Solution). Dari hasil penelitian hubungan pelaksanaan cuci tangan oleh perawat sebelum dan sesudah berinteraksi egan pasien tentang pencegahan infeksi nosokomial Maka Ha diterima dan Ho ditolak. Terdapat Hubungan yang signifikannya antara Pengetahuan dengan kepatuahn cuci tangan oleh perawat sebelum dan sesudah berinteraksi degan pasien tentang pencegahan infeksi nosokomial di Rs ptpn 2 bagkatan kota binjai, sehingga diharapkan pada responden untuk mencari pengetahuan yang lebih luas lagi mengenai langkah-langkah dan kepatuhan terhadap cuci tangan.
\end{abstract}

Kata kunci : Hubungan Pelaksanaan Cuci Tangan Oleh Perawat, Pencegahan Infeksi

\begin{abstract}
Washing your hands is a simple thing to remove dirt or germs and minimize germs that are in your hands, by pouring water over. and can be done by adding certain ingredients such as soap. With this connection the implementation of hand washing by nurses before and after interacting with patients about prevention of infection, this type of research is a survey research method used to collect data or information about the success of the implementation of hand washing. The population in this study was nurses. The sample used was disobedience to nurses in hand washing before and after interacting with patients. The sampling technique is total sampling. Data analysis with chi-square test technique using the SPSS (Statiscal Product and Service Solution) program. From the results of the study the relationship between the implementation of hand washing by nurses before and after interacting with patients about prevention of nosocomial infections So $\mathrm{Ha}$ was accepted and Ho was rejected. There is a significant relationship between Knowledge and hand washing by nurses before and after interacting with patients about prevention of nosocomial infections at Rs. Ptpn 2 for the city of Binjai, so that respondents are expected to seek more knowledge about steps and compliance with hand washing.
\end{abstract}

Keywords: Relationship of Hand Washing by Nurses, Prevent Infection

\section{PENDAHULUAN}

Rumah sakit merupakan tempat yang sangat komplek dalam pelayanan yang cukup kompleks karena dilengkapi fasilitasfasilitas yang cukup sederhana hingga yang modern dan canggih. Rumah sakit merupakan sebuah unit pelayanan medis tentunya tak lepas dari pengobatan dan perawat penderita-penderita dengan khusus penyakit infeksi, dengan kemungkinan adanya macam-macam mikroba sebagai penyebabnya (Herlambang dan Murwani, 2012). 
Hal ini yang merupakan kompleksitas sebuah rumah sakit adalah adanya sejumlah orang/personil secara serempak, berinteraksi langsug ataupun tidak langsung, mempunyai kepentingan dengan penderita-penderita yang dirawat di rumh sakit, contohnya tenaga medis seperti dokter, perawat, bidan, dan penunjangpenunjang lainnya, yang berhadapan dengan pasien. Pasien yang beradaa dalam lingkungan perawatana kesehatan data beresiko tinggi mendapatkan infeksi (Darmadi, 2008).

Infeksi adalah invasi tubuh atau pathogen mikroorganisme yang mampu menyebabkan sakit.Jika mikroorganisme gagal menyebabkan cedara yang serius terhadap sel atau jaringan, infeksi disebut asimtomatik dan yang terdapat melalui dari ligkungan atau tenaga kesehatan, ini disebut infeksi nasokomial (Septriari, 2012).

Infeksi nosokomial dikenal pertama kali pada tahun 1847 oleh Semmelwis dan hingga saat ini tetap menjadi masalah yang cukup menyita perhatian.Sejak tahun 1950 infeksi nosokomial mulai diteliti dengan sungguh-sungguh di berbagai Negara, terutama Amerika Serikat dan Eropa.Insiden infeksi nosokomial berlainan antara satu rumah sakit dengan rumah sakit laninnya. Angka infeksi nosokomial yang tercatat di berbagai Negara berkisar antara $3,3 \%-9,2 \%$, artinya sekian persen pendrita yang tertular penyakit infeksi nasokomial dan dapat terjadi secara akut atau secara kronis (Darmadi, 2008).

Hasil penelitian yang di lakukan World Healt Organization(WHO, 1987) pada 55 rumah sakit di 14 Negara sedang berkembang di empat wilayah meliputi Eropa, Meditrania Timur, Asia Tenggara dan Pasifik Barat menemukan rata-rata $8,7 \%$ pasien rawat inap menderita infeksi nasokomial. Jadi setiap saat terdapat 1,4 juta pasien diseluruh dunia terkena komplikasi infeksi yang didapat di ruamh sakit. Mayone (1998 dalam tientjen, 2004) menanyakan bahwa survey tertinggi infeksi nasokomial di laporkan dan wilayah Timur Tengah Mediterania dan Asia Tenggara masing-masing sebesar $11,8 \%$ dan $10 \%$.

Di Indonesia kejadian infeksi nasokomial pada jenis/tipe rumah sakit sangat beragam. Penelitian yang dlakukan oleh Depkes RI pada tahun (2004) diperoleh data proposi kejadian infeksi nosokomial di rumah sakit perintah dengan jumlah pasien 1.2527 orang dari jumlah pasien beresiko 160.417 (55,1\%), sedangkan untuk rumah sakit swasta dengan jumlah pasien 991 pasien dari jumlah pasien beresiko 130.047(35,7\%). Rumah sakit ABRI dengan jumlah pasien 254 dari pasien beresiko $1.672(9,1 \%)$. WHO-Depkes menyatakan bahwa standar rawat inap mendapat infeksi nosokomial memiliki standar maksimal 1,5\% (darmadi, 2008).

Cuci tangan merupakan salah satu penerapan salah satu perawat dalam pencegahan infeksi nasokomail, dimana kebersihan tangan adalah suatu prosedur tindakan memberikan tangan menggunakan sabun/antiseptic di bawah air mengalir atau dengan menggunakan handdrub yang bertujuan untuk menghilangkan kotoran dari kulit secara mekanis dan mengurangi jumlah mikroorganisme sementara. Persatuan pengendalian infeksi Indonesia (Perdalin, 2010)

Menurut Sumurti (2008), cuci tangan dilakukan untuk mengangkat mikroorganisme yang ada di tangan, mencegah infeksi silang, menjaga kondisi steril, melindungi diri dan pasien dari infeksi silang, menjaga kondisi steril, melindungi diri dan pasien dari infeksi, dan memberikan perassan segar dan bersih. Prosedur cuci tangan dilakukan sebelum dan sesudah kontak dengan pasien

Infeski nosokomial dapat terjadi kepada penderita, tenaga kesehatan, jug setiap orang yang datang ke rumah sakit. Infeksi yang ada di pusat pelayanan kesehatan ini dapat ditularkan atau diperoleh melalui petugas kesehatan, orang sakit, dan pengunjung yang berstatus karier atau kondisi rumah sakit.Angka kejadian infeksi nosokomial dapat dijadikan sebagai tolak ukur mutu pelayanan rumah sakit. Dalam meningkatkan mutu pelayanan dan meminimalisirkan terjadinya infeksi nosokomial dibutuhkan kerja sama dan tingkat kepatuhan dalam pencegahan infeksi nosokomial di rumah sakit (Numd, 2012). 
Kelman expired menyakatan kepatuhan pelaksanaan tindakan dimulai dari individu mematuhi anjuran tanpa kerelaan karena takut hukuman dan sanksi. Tahap identifikasi adalah kepatuhan karena merasa diawasi.Jadi pengukuran kepatuhan melauli identifikasi adalah sementara dan kembali lagi tidak patuh apabila sudah merasa tidak diawasi.Khususnya kepada tenaga kesehatan di rumah sakit yaitu perawat yang bayak tidak patuh dalam pengendalian infeksi nosokomial, apabila tidak diawasi dari manajemen tertinggi di rumah sakit sehingga dapat menyebabkan terjadinya masalah buat pasien dan perawat yang sakit makin sakit dan sehat menjadi sakit.

Upaya peningkatan mutu pelayanan rumah sakit sangat penting dalam meminimilasirkan terjadinya penambahan penyakit yang dialami klien yang mendapatkan perawatan di rumah sakit.Bagi tenaga kesehatan khusus nya perawat, di harapkan untuk memperhatikan serta mengontrol resiko penularan infksi baik individu ataupun lingkungan. Seperti mencuci tangan sebelum dan sesudah melakukan tindakan dan penggunaan alat pelindung, merupakan tindakan yang dapat meminimalisirkan terjadinya infeksi. Saat melakukan proses keperawatan khususnya ruangan (ICU).

Berdasarkan fenomena-fenomena yang ada maka peneliti tertarik untuk meneliti kembali tingkat kepatuhan perawat dalam penerapan infeksi nosokomial khususnya di rumah sakit Bangkatan Binjai, karena banyak perawat tidak mengikuti aturan-aturan yang dibuat oleh rumah sakit dan selalu selalu menganggap mudah dalam tugas dan tanggung jawab sebagai tanaga medis dan sarana kesehatan sehingga menyebabkan kerugian besar bagi pasien yang datang berobat ke RS Bangkatan Binjai.

\section{HASIL PENELITIAN}

Jenis penelitian ini adalah penelitian deskritif korelasi yaitu penelitian yang di lakukan untuk menganalisis ada tidaknya hubungan antara dua variabel yaitu penelitian antara variabel independen (pelaksanaan cuci tangan oleh perawat sebelum dan sesudah berinteraksi pada pasien tentang infeksi nosokominal di RS PTP II Bangkatan Binjai) dengan variabel dependen (ada hubungan, tidak ada hubungan) Populasi dalam penelitian ini adalah semua perawat berlatar belakang D3 keperawatan. Populasi dalam penelitian ini adalah semua perawat berlatar belakang D3 keperawatan. Sampel dalam penelitian ini adalah anggota populasi yang memiliki kriteria inkluksi sebagai berikut sebanyak 25 responden. Tehnik pengambilan sampel penelitian dilakukan dengan tehnik proportionate simple sampling, yaitu simple penelitian pada setiap ruangan di tetapkan berdasarkan jumlah perawat dengan cara.

Tabel 4.1 Distribusi $\quad$ Frekuensi Responden Berdasarkan Umur Di RS PTPN II Bangkatan Binjai Tahun Tahun 2017

\begin{tabular}{cccc}
\hline No & $\begin{array}{c}\text { Umur } \\
\text { (Tahun) }\end{array}$ & $\begin{array}{c}\text { Frekuensi } \\
\text { (Orang) }\end{array}$ & $\begin{array}{c}\text { Persentase } \\
(\boldsymbol{\%})\end{array}$ \\
\hline 1 & $27-30$ & 13 & $52 \%$ \\
2 & $31-35$ & 6 & $24 \%$ \\
& $36-45$ & 6 & $24 \%$ \\
\hline Jumlah & 25 & $100 \%$ \\
\hline
\end{tabular}

Berdasarkan tabel diatas dapat diketahui bahwa dari 25 responden yang berusia 27-30 tahun sebanyak 13 orang (52\%), yang berusia 31-35 tahun sebanyak 6 orang (24\%), yang berusia 36-45 tahun sebanyak 6 orang (24\%).

Tabel $\quad 4.2 \quad$ Distribusi $\quad$ Frekuensi Responden Berdasarkan Pendidikan Di RS PTPN II Bangkatan Binjai Tahun 2017

\begin{tabular}{cccc}
\hline No & $\begin{array}{c}\text { Pendi } \\
\text { dikan }\end{array}$ & $\begin{array}{c}\text { Frekuensi } \\
\text { (Orang) }\end{array}$ & $\begin{array}{c}\text { Persen- } \\
\text { tase (\%) }\end{array}$ \\
\hline 1 & S1 & 10 & $40 \%$ \\
2 & D3 & 12 & $48 \%$ \\
3 & SMK & 2 & $8 \%$ \\
& S2 & 1 & $4 \%$ \\
\hline Jumlah & 25 & 100 \\
\hline
\end{tabular}

Berdasarkan tabel diatas dari 25 responden dapat diketahui yang berpendidikan D3 sebanyak 12 orang 
(48\%), yang berpendidikan S1 sebanyak 10 orang $(40 \%)$ dan yang berpendidikan SMK sebanyak 2 orang (8\%), pendidikan S2 1 orang (4\%).

Tabel 4.3 Distribusi Frekuensi

Responden Berdasarkan Jenis Kelamin

Di RS PTPN II Bangkatan Binjai Tahun 2017

\begin{tabular}{cccc}
\hline No & $\begin{array}{c}\text { Jenis } \\
\text { Kelamin }\end{array}$ & $\begin{array}{c}\text { Frekuensi } \\
\text { (Orang) }\end{array}$ & $\begin{array}{c}\text { Persenta } \\
\text { se (\%) }\end{array}$ \\
\hline 1 & Laki-laki & 8 & $32 \%$ \\
2 & Perempuan & 17 & $68 \%$ \\
\hline & Jumlah & 25 & $100 \%$ \\
\hline
\end{tabular}

Berdasarkan tabel diatas dapat diketahui dari 25 responden yang berjenis kelamin Laki-laki sebanyak 8 orang $(32 \%)$ orang dan yang berjenis kelamin perempuan sebanyak 17 orang (68\%).

Tabel 4.4 Distribusi Frekuensi Responden Berdasarkan pelaksanaan sebelum dan sesudah Di RS PTPN II Bangkatan Binjai Tahun 2017

\begin{tabular}{cccc}
\hline No & $\begin{array}{c}\text { Pelaksa } \\
\text { naan }\end{array}$ & $\begin{array}{c}\text { Frekuen } \\
\text { si } \\
\text { (Orang) }\end{array}$ & $\begin{array}{c}\text { Persentase } \\
(\mathbf{\%})\end{array}$ \\
\hline 1 & Baik & 11 & $44 \%$ \\
2 & Cukup & 7 & $28 \%$ \\
3 & Kurang & 7 & $28 \%$ \\
\hline Jumlah & 25 & $100 \%$ \\
\hline
\end{tabular}

Berdasarkan tabel diatas dapat diketahui dari 25 responden yang melaksanaakan cuci tangan dengan baik berjumlah 11 orang (44\%), dan yang cukup 7 orang $(28 \%)$, dan yang melaksanakan cuci tangan kurang 7 orang(28\%).

Tabel 4.5 Distribusi Frekuensi Berdasarkan Pengetauan Perawat Di RS PTPN II Bangkatan Binjai Tahun 2017

\begin{tabular}{cccc}
\hline No & Pengetahuan & $\begin{array}{c}\text { Freku } \\
\text {-ensi }\end{array}$ & $\begin{array}{c}\text { Persen- } \\
\text { tase } \\
(\boldsymbol{\%})\end{array}$ \\
\hline 1 & Baik & 9 & $35 \%$ \\
2 & Cukup & 9 & $36 \%$ \\
3 & Kurang & 7 & $28 \%$ \\
\hline & Jumlah & 25 & $100 \%$ \\
\hline
\end{tabular}

Berdasarkan tabel di atas dapat di ketahui dari 25 responden yang berpengetahuan baik adalah 9 orang (35\%), dan yang berpengetahuan cukup 94.6 orang (36\%), dan yang berpegetahuan kurang 7 orang $(28 \%)$.

Tabel 4.6 Distribusi Frekuensi

Pencegahan Infeksi Nosokomial Di RS

PTPN II Bangkatan Binjai Tahun 2017

\begin{tabular}{clcc}
\hline No & $\begin{array}{c}\text { Pencegahan } \\
\text { Infeksi } \\
\text { Nosokomial }\end{array}$ & $\begin{array}{c}\text { Frek } \\
\text { uensi }\end{array}$ & $\begin{array}{c}\text { Persenta- } \\
\text { se (\%) }\end{array}$ \\
\hline 1 & Baik & 11 & $44 \%$ \\
2 & cukup & 7 & $28 \%$ \\
3 & kurang & 7 & $28 \%$ \\
\hline & Jumlah & 25 & $100 \%$ \\
\hline
\end{tabular}

Berdasarkan table di atas dapat di ketahui dari 25 responden yang mencegah infeksi nosokomial baik berjumlah 11 orang(44\%) cukup 9 orang(36\%) dan yang kurang 7 orang $(28 \%)$

\section{PEMBAHASAN}

a. Umur

Berdasarkan tabel 4.1 diatas dari 25 responden yang memiliki umur 27-30 tahun sebanyak 13 orang (52\%), yang berusia 31-35 tahun sebanyak 6 orang (24\%), yang berusia 36-45 tahun sebanyak 6 orang $(24 \%)$.

\section{b. Pendidikan}

Berdasarkan tabel 4.2 di atas dapat diketahui dari 25 responden berdasarkan berpendidikan D3 sebanyak 12 orang (48\%), yang berpendidikan S1 sebanyak 10 orang $(40 \%)$ dan yang berpendidikan SMK sebanyak 2 orang (8\%), pendidikan S2 1 orang (4\%).

\section{c.jenis kelamin}

Berdasarkan tabel 4.3 diatas dari 25 responden berdasarkan berjenis kelamin Laki-laki sebanyak 8 (32\%) orang dan yang berjenis kelamin perempuan sebanyak 17 orang $(68 \%)$

d.pelaksanaan sebelum dan sesudah cuci tangan

Berdasarkan tabel 4.4 diatas dapat diketahui dari 25 responden yang melaksanakan cuci tangan dengan baik, berjumlah 11 orang (44\%), dan yang cukup 
7 orang (28\%), dan yang melaksanakan cuci tangan kurang 7 orang( $28 \%$ )

\section{e. Pengetahuan perawat}

berdasarkan table 4.5 di atas dapat

di ketahuidari 25 responden yang pengetahuan baik adalah 9 orang $(35 \%)$, yang berpengetahuan cukup 9 orang(35\%), dan yang pengetahuan kurang 7 orang.

f. Hubungan pelaksanaan cuci tangan oleh perawat sebelum dan sesudah berinteraksi degan pasien, tentang pencegahan infeksi nosokomial.

Hubungan pelaksanaan cuci tanga dengan pencegahan infeksi nosokomial dapat di liat dengan uji kolerasi dapat di ketahui nilai $\mathrm{t}$ hitung, 4,180 dan $\mathrm{t}$ table 0,456 yang berarti bahwa thitung $>4,180 \mathrm{t}$ table 0,456 maka Ho di tolak dan $\mathrm{Ha}$ diterima . hal ini berarti ada hubungan pelaksanaan cuci tangan oleh perawat sebelum dan sesudah berinteraksi degan pasien.

\section{KESIMPULAN}

1. Penelitian dapat di lakukan dengan baik, berkat adanya kerjasama dari berbagai pihak.

2. berdasarkan umur responden yang paling dominan yang mempunyai umur 27-30 sebanyak 13 orang(52\%) yang berumur 31-35 tahun berjumlah 6 orang (24\%), dan yang berumur 36-45 sebanyak 6 orang $(24 \%)$.

3. Berdasarkan tingkat pendidikan yang paling banyak yaitu S1 sebanyak 10 orang $(40 \%)$. D3 sebanyak 12 orang $(48 \%)$ dan S2 sebanyak 1 (4\%)

4. Berdasarkan jenis kelamin yang paling dominan adalah yang mempunyai umur laki laki 8 orang(32\%). Perempuan 17 Orang $(68 \%)$.

5. Berdasarkan pelaksanaan yang dominan yaitu pengetahuan baik 11 orang $(44 \%)$. Sedangfkan pengetahuan cukup sebanyak 7 orang (28\%) dan yang kurang 7 orang $(28 \%)$

6. Berdasarkan pengetahuan perawat yang paling dominan yaitu, baik berjumlah 9 orang $(35 \%)$ cukup 9 orang $(36 \%)$ dan yang kurang 7 orang (28\%).
Dari hasil penelitian yang sudah dijelaskan, maka penulis ini memberikan beberapa saran, yaitu:

1. Di harapkan kepada seluruh pasien untuk lebih banyak memperoleh informasi tentang cuci tangan dengan baik

2. Diharapkan kepada perawat agar lebih memberikan informasi penyuluhan kepada pasien tentang hubungan cuci tangan dengan jelas

3. Semoga dapat menambah pengetahuan pasien tentang cuci tangan dengan baik sebelum melakukan aktivitas atau kegiatan.

\section{DAFTAR PUSTAKA}

Angrainy, R. 2010. Cuci Tangan Pakai Sabun untuk Menurunkan Angka Diare, di Daerah Istimewa Yogyakarta. Dalam Program Mendukung Prilaku Hidup Bersih. http.//www.prilaku hidup bersih.com.

Apriany, D. 2012. Perbedaan Prilaku Mencuci Tangan Sebelum dan Sesudah Kesehatan Kepada Anak Usia 4-5 Tahun. Jurnal Keperawatan. Cimahi: STIK Jendral Achmad Yani.

Depkes RI. 2013. Riset Kesehatan Dasar (Riskesdas) Jakarta : Badan . Penelitian dan Pembangunan.

Marquardt, W. H. 2004. Biologi of Diseanse Vectors, Elsevier Academic Press Publication California.

Mubarak, W,I. Chayatin, N. 2009. Ilmu Kesehatan Masyarakat Teori dan Aplikasi, Salembah Medika, Jakarta.

Waluyo, L,. 2009. Mikrobiologi Lingkugan. UMM Press. Malang. 